\title{
THE IMPACT OF PERCEPTION AND EVALUATION OF LINGUISTIC COMPETENCE ON LANGUAGE ATTITUDES
}

\begin{abstract}
Језички ставови, било позитивни или негативни, утичу на језички избор и праксе појединачних говорника. Они, осим тога, одражавају извесна уверења и доминанатне дискурсе о језичким варијететима и језику самом по себи. У случају мањинских језика, позитивни језички ставови могу да промовишу одржање језика, док негативни језички ставови могу довести до замене језика. У овом чланку бавићемо се језичким ставовима вишејезичних адолесцената према свом матерњем језику. Спровођењем интервјуа, не само да су добијени увиди у искуства говорника и њихови ставови, већ и фактори који доприносе формирању језичких ставова били су изложени. Стога, фокус овога рада је на фактору језичке компетенције, односно индивидуалне перцепције и оцене језичке компетенције.
\end{abstract}

Кључне речи: језички став, писменост, мултилингвизам, језичко образовање.

\section{Introduction}

Attitudes describe opinions and ideas of individuals further constituting wider social discourses. Language attitudes specifically describe the views of individual speakers about one language or language variety, which has a further impact on the personal and social use of language. Trudgill (2003: 73) describes language attitudes as follows:

The attitudes which people have towards different languages, dialects, accents and their speakers. Such attitudes may range from very favourable to very unfavourable, and may be manifested in subjective judgments about the 'correctness', worth and aesthetic qualities of varieties [...] Sociolinguistics notes that such attitudes are social in origin, but that they may have important effects on language behaviour, being involved in acts of identity, and on linguistic change $[. .$.$] .$ 
Language attitudes are to be understood as socially established and intertwined with language ideologies. When uncovering language attitudes internalized discourses reveal dominant ideas about languages and language varieties. In situated interactions speakers position themselves according to dominant language ideologies, thereby again exposing language ideologies in their attitudes.

Through positioning in discourses individuals express positive or negative language attitudes not only towards languages per se, but also towards their own linguistic repertoire. On a more individual level, language attitudes then influence personal language choices and practices leading to either language shift (cf. Weinreich 1953: 68) or language maintenance (cf. Coulmas 2005: 157).

Especially in multilingual contexts of ethnically heterogeneous societies, discourses on the discrepancy between majority and minority languages begin to manifest. The languages of migrants are hardly recognized as useful means of communication or attributed with value outside of the family domain (cf. May 2014; Blommaert, Collins \& Slembrouck 2005). Recent research has addressed a diverse range of topics related to the marginalization of minority languages in heterogeneous societies such as the connection between the multilingual repertoire and spaces (cf. Blommaert et al. 2005), origin-specific differences between language acquisition of immigrant children (cf. Brizić 2006), and approaches in multilingual language education (cf. Busch 2011; Creese \& Martin 2003).

Based on previous research the central concern of this paper is the correlation between language attitudes and linguistic competence of multilingual adolescents from migrant communities in the urban area of Graz, Austria. The main objective is to determine factors that influence individual language attitudes towards the speakers' home languages. One factor above all clearly shows a strong impact on the formation of language attitudes: linguistic competence, or rather the speakers' perception and evaluation of their own linguistic competence, which both conveys dominant language ideologies and forms language attitudes.

The general conception of linguistic competence describes knowledge of structural features, portraying a so-called ideal speaker hearer (cf. Chomsky 1965). This definition excludes social notions of language abilities, whereas communicative competence is defined as socially adequate 
language use among a speech community (cf. Hymes 1972). According to Blommaert et al. (2005: 211) both definitions assume competence to be a fixed concept either linked to structural knowledge or stable communities; by contrast they define linguistic competence as strongly associated with spatial spaces, meaning that language abilities might be acknowledged in one situation, but not in another: "We assume that people have varying language abilities - repertoires and skills with languages - but that the function and value of those repertoires and skills can change as the space of language contact changes" (Blommaert et al. 2005: 211).

In this paper, Blommaert et al.'s (2005) understanding of linguistic competence will be applied focusing on the participating speakers and how they perceive and evaluate their linguistic repertoire, while considering the overall social situations they are currently in. At this point it is important to discuss possibilities that are offered in Austria to acquire linguistic competence in home languages outside of the family domain.

In Austria acquiring competence in migrant languages is possible via so-called lessons in mother tongue during compulsory school. Lessons in mother tongue are offered as a voluntary exercise or elective subject, currently covering 25 languages in total (cf. Garnitschnig 2014). However, whether or not lessons can in fact take place depends on the availability of a teacher in the particular area and the amount of pupils enrolled. Also, the commitment of parents - whether they want their child to acquire skills in their home language or not - plays a significant role. During higher education pupils can choose among a variety of volitional subjects such as languages. Concerning foreign languages nearly all Austrian schools offer English, followed by French, Italian, Spanish and Russian (cf. BMBF 2015). Occasionally other language courses in languages of neighbouring countries, migrant languages or other languages are offered collectively. However, the teaching of English is in the center of attention in early language learning with the aim of achieving high proficiency in English (cf. ÖSZ, BMUKK \& BMWF 2009: 17).

\section{Methodology}

To uncover ideologies and attitudes the method of language biogra-

phies (cf. Rosenthal 1995; Fischer-Rosenthal \& Rosenthal 1997; Schütze 
1984) is appropriate, because it helps to reveal insights into complex living situations through personal descriptions. In addition, by applying language biographies aspects such as the influence of ideologies, emotions or imaginations can be considered intensively (cf. Busch 2013: 17). In this project language biographies were collected using narrative interviews with nine adolescents aged 18 to 25 with migratory backgrounds.

Interviews were held in an interactive way focusing on the informants narrations. At the beginning informants were asked to recall their life experiences while paying special attention to all occurrences and memories that are related to language use, language acquisition or language in general. Afterwards further related topics such as nationality, dialect or domain specific language use were inquired.

In sum nine narrative interviews were held. Informants were both first and second generation migrants, it was however essential that they have spent at least ten years in Austria, so that they have sufficient proficiency in German and feel comfortable with participating in interviews in German. Also it was assumed that a certain amount of time would be necessary to internalise dominant ideologies and discourses in one particular area. The gathered data was analyzed by applying a qualitative content analysis (cf. Mayring 2002: 114ff.; Mayring 2010: 49) to categorize mentioned topics in a systematic and comprehensible manner.

\section{Perception of linguistic competence}

The following part will address one factor that has repeatedly emerged in the held narrative interviews. The speakers' perception of linguistic competence and their evaluation appeared to have a significant impact on whether they show positive or negative attitudes towards their home languages. Section 3.1. provides examples of the comparison between linguistic competence in the home language and in another language. Section 3.2. goes on to discuss the relevance of literacy skills visible in informants' narrations.

\subsection{Comparing the linguistic repertoire}

The extent of one's linguistic competence is generally seen as indicating knowledge and demonstrating who can be considered a bilingual 
speaker (cf. Busch 2013: 45). However, also among speakers themselves, who are affected by standard language ideologies (cf. Milroy 2001; Lippi-Green 2012; Cameron 1995) and a marginalization of the minority language (cf. May 2014;), linguistic competence decides whether or not speakers view themselves as "fully" bilingual. In this study, informants compare their linguistic competences in their home language with competences in other languages. Informants either compare their linguistic competences to those in German, which can be seen in example (1) and (2), or compare it to languages such as English.

(1) extract of interview with B.

[...]Ich sprech noch meine Muttersprache zwar nicht mehr so fließend wie Deutsch mit ein bisschen einem steirischen Akzent aber eigentlich geht's noch lesen und schreiben halbwegs[...]

[...] I still speak my mother tongue but not as fluent as German with a little bit of a Styrian accent but actually it is fine reading and writing to some extent [...]

(2) extract of interview with A.

[...] Jetzt kann ich besser Deutsch, weil meine Muttersprache ja eigentlich Rumänisch ist [...]

[...] Now I am better in German, even though my mother tongue actually is Romanian [...]

German is either a language that has been acquired early in life as a second first language or later on during primary education. German as the national language of Austria is the dominant language of public domains attributed with high social status. Furthermore, informants frequently compare linguistic competence in their home language with proficiency in English, a language which can be considered a third language acquired later on in school, see example (3) for instance. 
(3) extract of interview with D.

Und ich war dann auch im Gymnasium immer sehr gut in Englisch eigentlich und würd zum Beispiel jetzt sagen, dass ich besser Englisch kann als Griechisch [...]

And then I was also in high school always very good in English actually and I would for example say that I am better in English than in Greek [...]

In relation to minority languages English appears in quite a different context-it is an institutionalized language linked with high prestige and functionality and is taught very early on in schools. The majority of Austrian schools focus on the teaching of English as a second language starting at the primary level(cf. ÖSZ et al. 2009: 17). The educational system plays a significant role in conveying language ideologies through discoursive practices. Schools are powerful institutions where the standard language is communicated, thereby providing instructions on what is right or wrong in one language and what languages or language varieties are appropriate or not (cf. Lippi-Green 2012; Cameron 1995; Shohamy 2006). The recognition of English as a global lingua franca works most of the time against the maintenance and support of minority languages (cf. May 2014).

The examples above emphasize that speakers of minority languages themselves perceive their linguistic competences in one language in relation to linguistic competences in another language. In general, these languages are assigned with high prestige, while dominant language ideologies support notions of what counts as a useful language in public domains as well as for economic and social advancement. Informants notably stress any missing skills in their first languages leading to insecure descriptions of their linguistic proficiency, which can be seen in example (4), where B. elaborates on her pronunciation in Portuguese. She describes her pronunciation in a negative way revealing insecurity and embarrassment, while at the same time states a connection between linguistic competence and the right to name Portuguese her mother tongue.

(4) extract of interview with B.

B.: Und dann, ja, was mir halt auch nicht gefällt ist, dass ich, ich selber das raushöre, dass sich mein Portugiesisch wirklich schrecklich 
anhört für mich. Also sie sagt zumBeispiel, die Freundin, es ist nicht so schlimm [...] Aber ich, ich weiß nicht, für mich hört sich das so schrecklich an.

C.: Bist ganz kritisch?

B.: Ja. ((lachen)) Weil irgend-, man sagt ja "deine Muttersprache und so", aber ich weiß es nicht.

B.: And then, well, what I also don't like is, that I, I can hear myself, that my Portuguese sounds really bad to me. Well she says for example, my friend, she says it is not so bad [...] But I, I don't know, to me it sounds so bad.

C.: You are certainly critical?

B.: Yes ((laughing)) because some-, one says "your mother tongue and so on", but I don't know.

Linguistic insecurity is a term coined by Labov (1966) describing insecure self-evaluation of one's own language practices. He noticed insecure behaviour in his study on language use and evaluation of local varieties of English in New York city. Labov further describes, that evaluations and attitudes are in direct relation with assigned prestige of the respective languages (cf. Labov 1966: 500). Insecurities with regard to language competence therefore not necessarily depend on actual proficiency, but are linked with prestige of the language or language variety in this particular space. Examples (1) to (4) not only show speakers' linguistic insecurities, their awareness of missing linguistic competences and comparisons between their linguistic repertoire, but above all they reflect dominant discourses manifested in a negative prestige of migrant languages, that gets supported by ideologies promoting a national (and standard) language, global languages and devaluation of minority languages.

\subsection{Literacy acquisition}

Literacy proficiency, the ability to read and write, is a topic that appeared frequently in the gathered narrative interviews. Several times informants mention certain skills in their reading and writing abilities in the home language, which can be seen for instance in example (5): 
(5) extract from interview withA.

[...] ich bin schon zweisprachig nur irgendwie kommich mir ein bisschen falsch zweisprachig vor, weil ich gern schon also also es wär schon (.) als Zweisprachiger könnt ich meine Muttersprache vielleicht gleich gutwie die Sprache wo ich aufwachs also aber ich würd jemanden ja wenn einfachvon Kind an zwei (.) Sprachen oder mehr Sprachen lernt und dann auch (.) kann obwohl es nicht unbedingt das Können wie gesagt ich kann's ich kann's reden ich kann's ja aber net literataber trotzdem empfind' ich mich als zweisprachig [...]

[...] I am bilingual but somehow I feel like being kind of a fake bilingual, because I would like, well it would be nice (.) as a bilingual I would maybe be as good in my mother tongue as in the languages where I grew up, but I would someone, well If someone from early childhood on would learn(.) two languages or more and then also can [speak and write] (.) although it is not necessarily the ability like I said I can I can speak I can yes, but I am not literate, but even so I feel like I am bilingual [...]

A. addresses her linguistic competences and emphasizes the importance of learning a language and acquiring literacy skills so as to be considered proficient in the language. She mentions doubts in her linguistic abilities in Romanian, because she is competent in producing as well as comprehending the language, but not as competent in writing and reading. She further reveals that Standard Romanian is not part of her repertoire, due to the fact that she has acquired a regional variety from her parents and has never participated in home language classes. Her insecurity of not knowing Standard Romanian leads to her subordinating her first language (cf. Lippi-Green 2012: 66ff.). At the same time A. talks in example (6) about her partaking in one language course on Romanian at university, where she gets the opportunity to learn the standard language form.

(6) extract from interview with A.

A.: [...] und hab eben den Rumänisch-Kurs auchnoch so nebenbei, also es ist so ein Einführungskurs, das heißt man lernt halt wirklichso 
die Grundlagen von der Grammatik und so, aber wie gesagt es ist viel, wasich noch gar nicht gewusst hab, dass das ist oder was ich halt immer falsch gesagthab so wie Plural und Singular, das hab ich halt immer irgendwie gemacht,[...] das ist ganz cool, dass ich das jetzt endlich malgescheit lern. ((lachen))

A.: [...] and I also take a Romanian course besides, well it is an introductory course, which means you really learn the basics of Grammar and so on, but like I said, it is much that I haven't known, that is or that I have also said wrong like plural and singular, I have always done it somehow, [...] it is quite cool, that I finally learn it properly ((laughing))

Informants are aware that literacy skills in their home languages are a necessary requirement, but that acquisition was not possible and/or they did not want to acquire it during early childhood. Besides, some mentioned that they enrolled later in various courses to compensate for the missed opportunities to acquire literacy during childhood, telling about their goals and motivations. Moreover, informants associated incomplete competences with deficits, like illustrated by N. in example (7).

(7) extract from interview with $\mathrm{N}$ :

[...] so wirklich zu lesen ja, dass ich mich wirklich damit beschäftigt hab ja weil ich mir gedacht hab ich möcht es eigentlich können nur vorher hab ich mir gedacht ich kann eh reden reicht eh und dann hab ich mir gedacht nein, wenn ich das irgendwann einmal im Studium haben möcht oder bei irgendeiner Bewerbung oder sonst irgendwas das abgib kann ich nicht sagen ich kann Polnisch wenn ich dann kein Wort schreiben kann und nicht lesen kann [...]

[...] to really read, well, that I really engaged in it, well because I thought that I actually wanted to know it, just before, I thought I can speak that is enough and then I thought no, if I really want to use it in my studies or claim it in any application or something else I cannot say that I am proficient in Polish if I can't write a word or read [...] 
Milroy (cf. 2001: 537) has noted, that linguistic knowledge needs to be acquired in a formal manner to count as adequate, something which basically happens in schools under supervision of someone who knows and communicates rules of a language (cf. Cameron 1995). Literacy itself is an important requirement for social and economic positions in literate cultures (cf. Maas 2010; Bialystok 2001: 152), however in the context of minority languages acquisition of literacy skills in the majority language are still predominantly important.

Since informants realize the need to acquire further skills in their first language, they show ambitions to engage themselves in the process. Some already had the possibility to gain knowledge in their home language during early childhood, for example informant P., who took advantage of lessons in mother tongue during primary school, or informant S., who learnt literacy skills from his grandmother. Support of family and parents, thereby, seems to play a crucial role. Example (8) cites S. talking about how he acquired reading and writing skills during the times he spent with his grandmother in Bosnia.

(8) extract from interview with S:

S.: [...] ich hab damalswo ich, wo ich im Sommer immer zusammen mit meiner Oma war, hab ich gelesenXX, das sind so Sportnachrichten, und da habe ich glaube ich das Lesen gelerntund Schreiben de facto dann auch. Ist mir nämlich auch ganz wichtig, dass man eine Sprache, die man spricht, lesenund schreiben kann.

S.:[...] at that time I have, when I, when I always spent the summer with my granny, I read XX, these are kind of sports news, and then I have I think also de facto learnt to read and write. Because it is also very important to me, than one can also read and write a language, that one speaks.

In conclusion it can be noted, that speakers' perception and evaluation of their own linguistic competences are crucial for developing a positive language attitude towards their home languages and language practices. Competences on all levels, oral als well as literate and knowledge 
of the standard language variety influence the speakers view of their language proficiency. In addition, it appeared that support received externally such as educational opportunities given to learn the language and support from the family fosters a connection to the home language.

\section{Conclusion}

Because language attitudes and ideologies are ever changing concepts continuously affected by current life situations (cf. Blackledge \& Pavlenko 2001), the gathered data and analysis can only reflect the informants' language attitudes at this moment in time. Nevertheless, the results may indicate that language attitudes are partly determined by the speaker's perception and evaluation of her or his own linguistic competence.

The findings strongly support the view that dominant language ideologies, such as a standard language ideology (cf. Milroy 2001; LippiGreen 2012), are expressed by the speakers, leading to negative attitudes and reluctance to maintain or further engage in one's home language. Here, the importance of offering language education in home languages needs to be stressed. Home language education shall be accessible for everyone (cf. Cummins 2005), while receiving enough support from politicians and practitioners. Benefits of education in home languages are manifold, from cultural and linguistic maintenance as a marker of identity to several psychological, sociological and educational advantages (cf. UNESCO 1953). Even though informants have limited opportunities to acquire literacy in their home languages, they reveal an eagerness to maintain their home language and want to acquire further skills such as literacy in their home languages. Overall, the notion of "full competences" is reflected by speakers. Especially literacy is assumed to be a basis for general knowledge of the language, granting them the right to claim themselves as competent speakers and bilingual, while a deficit is perceived as "incomplete competences" in a literate society (cf. Maas 2010). Obviously, additional research is necessary to completely understand the complex language attitudes of multilingual speakers and possible consequences of language attitudes. 


\section{Transcription conventions}

(.) short noticeable pause

(( )) nonverbal signs or sounds described in round brackets

XX removed proper names

[] additional information added by the author for better understanding of translation

\section{References:}

Bialystok, E. (2001). Bilingualism in Development: Language, Literacy, and Cognition. Cambridge: Cambridge University Press.

Blackledge,A., \& Pavlenko,A. (2001). Negotiation of identities in multilingual contexts. International Journal of Bilingualism, 5(3), 243-257.

Blommaert, J., Collins, J., \& Slembrouck, S. (2005). Spaces of multilingualism. Language \& Communication, 25, 197-216.

Brizić, K. (2006). The secret life of languages. Origin-specific differences in L1/L2 acquisition by immigrant children. International Journal of Applied Linguistics, 16(3), 339-362.

Bundesministerum für Bildung und Frauen [BMBF]. (2015). Current Issues of Educational Policy in Austria. https:/www.bmbf.gv.at/ enfr/school/educ/heading1.htm4596.html (17.11.2015)

Busch, B. (2011). Trends and innovative practices in multilingual education in Europe: An overview. International Review of Education, 57(5), 541-549.

Busch, B. (2013). Mehrsprachigkeit. Wien: Facultas.

Cameron, D. (1995). Verbal Hygiene. London, New York: Routledge.

Chomsky, N. (1965). Aspects of a Theory of Syntax. Cambridge: MIT Press.

Coulmas, F. (2005). Sociolinguistics - The study of speakers' choices. Cambridge: Cambridge University Press.

Creese,A., \& Martin, P. W.(Eds.).(2003). Multilingual classroom ecologies: inter-relationships, interactions, and ideologies. Clevedon, Buffalo: Multilingual Matters.

Cummins, Jim. (2005). A Proposal for Action: Strategies for Recognizing Heritage Language Competence as a Learning Resource within the 
THE IMPACT OF PERCEPTION AND EVALUATION OF LINGUISTIC COMPETENCE...

Mainstream Classroom. Modern Language Journal, 89(4), 585-592. Fischer-Rosenthal, W., \& Rosenthal, G. (1997). Narrationsanalyse biographischer Selbstrepräsentation. In R. Hitzler \& A. Honer (Eds.), Sozialwissenschaftliche Hermeneutik: Eine Einführung (pp. 133-164). Opladen: Leske Budrich.

Garnitschnig, I. (2014). Der muttersprachliche Unterricht in Österreich. Statistische Auswertung für das Schuljahr 2013/14. Wien: Bundesministerium für Bildung und Frauen.http://www. schulemehrsprachig.at/fileadmin/schule_mehrsprachig/redaktion/ Hintergrundinfo/info5-14-15.pdf (01.02.2015)

Hymes, D. (1972). On Communicative Competence. In J. B. Pride \& J. Holmes (Eds.), Sociolinguistics (pp. 269-293). Baltimore, USA: Penguin Education, Penguin Books Ltd.

Labov, W. (1966). The social stratification of English in New York City. Washington D.C.: Center for Applied Linguistics.

Lippi-Green, R. (2012). English with an accent: Language, ideology, and discrimination in the United States (2nd ed.). London, New York: Routledge.

Maas, U. (2010). Schriftkultur in der Migration - ein blinder Fleck in der Migrationsforschung. Grazer Linguistische Studien, 73, 151-168.

May, S. (2014). Contesting public monolingualism and diglossia: rethinking political theory and language policy for a multilingual world. Language Policy, 13(4), 371-393.

Mayring, P. (2002). Einführung in die Qualitative Sozialforschung: Eine Anleitung zu qualitativem Denken (5th ed.). Weinheim und Basel: Beltz Verlag.

Mayring, P. (2010). Qualitative Inhaltsanalyse: Grundlagen und Techniken (11th ed.). Weinheim und Basel: Beltz.

Milroy, J. (2001). Language ideologies and the consequences of standardization. Journal of Sociolinguistics, 5(4), 530-555.

ÖSZ, BMUKK, \& BMWF (Eds.). (2009). Sprach- und Sprachunterrichtspolitik in Österreich. Länderprofil. Language and Language Education Policy in Austria. Country Report.Graz, Wien: ÖSZ. https://www.coe.int/t/dg4/linguistic/Source/Profil_Austria_DE.pdf (01.03.2016) 
Rosenthal, G. (1995). Erlebte und erzählte Lebensgeschichte: Gestalt und Struktur biographischer Selbstbeschreibungen. Frankfurt/Main, New York: Campus.

Schütze, F. (1984). Kognitive Figuren des autobiographischen Stegreiferzählens. In M. Kohli \& G. Robert (Eds.), Biographie und soziale Wirklichkeit: Neue Beiträge und Forschungsperspektiven (pp. 78-117). Stuttgart: Metzler.

Shohamy, E. G. (2006). Language policy: hidden agendas and new approaches. London, New York: Routledge.

Trudgill, P. (2003). A Glossary of Sociolinguistics. Edinburgh: Edinburgh University Press.

UNESCO. (1953). The Use of Vernacular Languages in Education. Paris: Unesco. http://unesdoc.unesco.org/images/0000/000028/002897EB. $\operatorname{pdf}(25.2 .2016)$

Weinreich, U. (1953). Languages in Contact: Findings and Problems. New York: Columbia University Press.

\begin{abstract}
Language attitudes, whether positive or negative, influence the language choices and practices of individual speakers. They furthermore reflect certain beliefs and dominant discourses about language varieties and language per se. In the case of minority languages, positive language attitudes may promote language maintenance, whereas negative language attitudes can lead to language shift. In this article multilingual adolescents' language attitudes towards their home languages will be addressed. By conducting narrative interviews, not only insights into the speakers'experiences and attitudes were obtained, but also factors that contribute to the formation of language attitudes were exposed. Hence, the focus of this paper lies on the factor of linguistic competence, or rather individual perception and evaluation of linguistic competence. This paper discusses the issue by providing examples, which illustrate that the perception of one's own linguistic competence significantly influences language attitudes and consequently alters language practices.
\end{abstract}

Keywords: Language attitude, literacy, multilingualism, language education. 
THE IMPACT OF PERCEPTION AND EVALUATION OF LINGUISTIC COMPETENCE...

\section{Biographical statement}

CHRISTINA KORB MA completed her Master's degree in Linguistics at the University of Graz and University of Iceland. She is currently an assistant and Phd candidate at treffpunkt sprachen - Plurilingualism Research Unit at the University of Graz. Her research interests include sociolinguistic topics such as language ideology, language policy and urban multilingualism. In her doctoral thesis she addresses the issue of de facto language policy in local linguistic heterogeneous schools applying ethnographic research methods and linguistic landscape analysis.

E-mail: korb.stina@gmail.com 